TEME, г. XLII, бр. 1, јануар - март 2018, стр. 17-34

Прегледни рад

DOI: $10.22190 /$ TEME1801017C

Примљено: 13. 4. 2016.

UDK 159.97:316.64-057.874

Ревидирана верзија: 2. 12. 2017.

Одобрено за штампу: 12. 3. 2018.

\title{
СТАВОВИ МАТУРАНАТА ПРЕМА СОЦИЈАЛНОЈ ИНТЕГРАЦИЈИ ОСОБА СА ИНТЕЛЕКТУАЛНОМ ОМЕТЕНОШТУ
}

\author{
Марија Цвијетић \\ Педагошки факултет у Сомбору, Сомбор, Србија \\ marija.cvijetic@pef.uns.ac.rs
}

\begin{abstract}
Апстракт
Циљ овог истраживања био је утврдити усмереност и интензитет ставова матураната према социјалној интеграцији особа са интелектуалном ометеношћу и испитати повезаности појединих карактеристика испитаника са њиховим ставовима. Узорак је чинио 95 матураната Гимназије „Душан Васиљев” из Кикинде. Смер и интензитет ставова испитан је применом Скале ставова према животу у заједници - форме за менталну ретардацију (CLAS-MR; Henry, Keys, Jopp, \& Balcazar, 1996), док су подаци везани за пол, претходно искуство контакта са особама са ометеношћу и интересовања за професионално бављење овом популацијом добијени упитником за испитивање социо-деомографских варијабли конструисаним за потребе овог истраживања.

Резултати су показали да су ставови матураната према социјалној интеграцији особа са интелектуалном ометеношћу позитивни на скали у целини и три од четири подскале примењеног инструмента. Наши испитаници исказали су позитиван став према оснаживању ових особа, њиховом укључивању у активности заједнице и доживљавању ових особа сличним себи. Негативан став испитаници су исказали кроз перципирану потребу особа са интелектуалном ометеношћу да буду смештене у заштићене животне и радне услове, ван шире заједнице. Повезаност ставова са полом, претходним искуством контакта, блиским контактом са особама са ометеношћу и интересовањем за професионално бављење популацијом особа са омете-ношћу није утврђена.

Имајући у виду претпоставку о утицају ставова на понашање особа према одређеној друштвеној групи, познавање ставова и детерминанти ставова младих особа према овој популацији, на прагу њиховог ступања у одрасло доба може дати корисне смернице за планирање и спровођење практичних поступака у циљу квалитетније интеграције особа са интелектуалном ометеношћу у заједницу у будућности.

Кључне речи: инклузија, интелектуална ометеност, матуранти, ставови, живот у заједници.
\end{abstract}




\title{
ATTITUDES OF HIGH SCHOOL GRADUATES ABOUT SOCIAL INTEGRATION OF PEOPLE WITH INTELLECTUAL DISABILITY
}

\begin{abstract}
The aim of this study was to determine the direction and intensity of high school graduates' attitudes towards social integration of persons with intellectual disability and examine correlation between certain characteristics of the subjects and their attitudes. The sample consisted of 95 high school graduates from "Dušan Vasiljev" secondary school in Kikinda. The direction and intensity of attitudes was examined by the Community Living Attitudes Scale - Mental Retardation Form (CLAS-MR; Henry, Keys, Jopp, \& Balcazar, 1996), while the data related to race, gender, previous experience of contact with people with disabilities and interests of career dealing with this population were obtained through the questionnaire for testing socio-demographic variables constructed for this survey.

The results showed that the attitudes of graduates towards social integration of people with intellectual disability are positive on the scale in general, and three of the four domains of the applied instrument. Our respondents expressed a positive attitude towards the empowerment of these people, their involvement in the community's activities and experiencing these people to themselves. The respondents expressed a negative attitude through the perceived need of people with intellectual disabilities to be placed in protected living and working conditions, beyond the wider community. Connection between the attitudes to gender, previous experience of contact, close contact with people with disabilities and interest for professional work with persons with disabilities was not established.

Bearing in mind the presumption about the influence of attitudes towards the behavior of a particular social group, the knowledge of attitudes and their determinants in young people towards this population, on the threshold of their entry into adulthood, can provide useful guidance for planning and implementing practical procedures with the aim of a higher quality integration of people with intellectual disabilities into the community in the future.
\end{abstract}

Key words: inclusion, intellectual disability, high school graduates, attitudes, community life.

\section{УВОД}

У протеклих неколико деценија на пољу бриге о особама са интелектуалном ометеношћу дошло је до значајног заокрета институционални третман и збрињавање особа у великој мери су напуштени и успостављен је систем живљења и обезбеђивања услуга у заједници. Данас се ометеност углавном посматра из био-психо-социјалне перспективе, у оквиру које се функционисање особе са ометеношћу у друштву сматра резултатом интеракције анатомских и физиолошких својстава особе и карактеристика њеног физичког и социјалног окружења. Стога је потребно упоредо разматрати потенцијале и ограничења саме особе, са једне стране, и могућности и захтеве њеног ужег и ширег окружења, са друге стране, како би се унапредило учешће особе са ометеношћу у активностима у заједници. 
Значај социјалне укључености и остваривања жељених друштвених улога особа са ометеношћу у различитим областима живота (образовање, запошљавање, рекреација, међуљудски односи) огледа се у повезаности учешћа у поменутим активностима са квалитетом живота (Schalock, Keith, Verdugo, \& Gómez, 2010).

Став представља оцењивање објекта мишљења. Објекат става обухвата било шта о чему особа може мислити, у опсегу од конкретног, попут ствари, па до апстрактног, попут људи, група и идеја (Bohner \& Dickel, 2011). Велики број теоретичара сматра да постоје три димензије ставова: когнитивна (уверења о објекту става), афективна (осећања према објекту става) и акциона (понашајне намере у односу на објекат става). Ставови према особама са интелектуалном ометеношћу могу се посматрати и као степен социјалне дистанце коју припадници опште популације желе да задрже између себе и особа са интелектуалном ометеношћу (Ouellette-Kuntz, Burge, Brown, \& Arsenault, 2010). Успешност инклузије особа са интелектуалном ометеношћу у великој мери зависи од ставова припадника опште популације према њиховој интеграцији у друштво (Burke et al., 2013; Pratt, 2010, према Lee, 2016). Стога, истраживање ставова као потенцијалних показатеља понашања особа типичне популације може дати смернице за планирање и остваривање интервенција усмерених на унапређење квалитета интеракција ове две друштвене групе.

Већина студија које су се бавиле ставовима према особама са интелектуалном ометеношћу била је усмерена на (а) психометријску процену ставова према особама са ометеношћу, (б) личне и демографске корелате ставова према особама са ометеношћу и (в) стратегије мењања ставова према овим особама. Као маргинализована група, особе са интелектуалном ометеношћу често су подвргнуте дискриминацији и друштвеној изолацији. Негативни ставови према овим особама могу у великој мери ограничити њихове изборе у различитим областима живота. Резултати истраживања спроведних у развијеним земљама често показују да већина испитаника сматра да особе са интелектуалном ометеношћу имају право да буду укључене у друштво. Упркос томе, ове особе често се наводе као врло непожељни партнери за друштвену интеракцију (Scior, 2011) или постоји амбивалентан однос према друштвеном контакту са њима (Scior, Addai-Davis, Kenyon, \& Sheridan, 2013). Ограничења у разумевању концепта интелектуалне ометености и погрешна уверења у вези са способностима и жељама особа са интелектуалном ометеношћу показали су се као показатељи веће друштвене дистанце и негативних ставова према инклузији и учествовању ових особа у различитим животним активностима (Ouellette-Kuntz et al., 2010; Scior et al., 2013). У односу на друге групе особа са ометеношћу или менталним обољењима, ставови према особама са интелектуалном ометеношћу 
углавном су позитивнији него према особама са психијатријским обољењима и негативнији у односу на особе са физичком или сензорном ометеношћу (Hernandez et al., 2000, према Милачић-Видојевић, Глумбић, \& Каљача, 2010; Scior, 2011).

Налази канадске студије у којој су узорак чинили чланови особља ангажованог у раду са особама са интелектуалном ометеношћу показују да већина испитаника има ставове који су конзистентни са филозофијом инклузије, али нису у складу са вредностима самозаступања и оснаживања особа са интелектуалном ометеношћу, које су веома важне за инклузивни покрет (Jones, Ouellette-Kuntz, Vilela, \& Brown, 2008). Резултати истраживања спроведеног у нашој средини са популацијом студената Универзитета у Београду показали су да су ставови према особама са интелектуалном ометеношћу умерено позитивни (резултати испитаника на скалама ставова у просеку су припадали средишњем рангу унутар позитивних вредности). Ставови студената према инклузији особа са интелектуалном ометеношћу у ширу заједницу негативно су повезани са ставовима према примени мера еугенике. Дакле, студенти који подржавају инклузију и оснаживање особа са интелектуалном ометеношћу мање одобравају спровођење мера еугенике у овој популацији. Тенденција искључења особа са интелектуалном ометеношћу и сагледавање као различитих од особа масовне популације одражава недостатак вредновања особа са интелектуалном ометеношћу, што води ка спремности да се примене мере еугенике (Милачић-Видојевић и сар., 2010).

Међу демографским карактеристикама особа типичне популације које су се у резултатима већег броја истраживања показале релевантним за ставове према особама са интелектуалном ометеношћу налазе се: старосно доба, образовни ниво, пол, професионални позив (занимање), као и претходно искуство контакта са особама са интелектуалном ометеношћу. Више образовање испитаника често се доводи у везу са њиховим позитивнијим ставовима према популацији особа са интелектуалном ометеношћу (Jones et al., 2008; Scior, 2011). Када је у питању пол, резултати студија углавном указују на позитивније ставове особа женског пола у односу на популацију мушког пола (Rice, 2009), док неки аутори не проналазе значајне разлике у вези са полом (Wozencroft, Pate, \& Griffiths, 2015). Млађе особе често су наклоњеније идеји инклузије и учешћа у друштву особа са интелектуалном ометеношћу него особе касније старосне доби (Jones et al., 2008; Scior, 2011). Значајну детерминанту ставова према особама са интелектуалном ометеношћу представља и професионално бављење овом популацијом. Ставови особа које су у оквиру свог радног ангажовања упућене на особе са интелектуалном ометеношћу углавном су позитивнији од ставова особа које се не баве професионално овом друштвеном групом (Rose, Kent, \& Rose, 2012). Такође, показа- 
тељ позитивнијих ставова је и постојање искуства контакта са овом популацијом, у виду рођачких, пријатељских или односа и познанстава друге врсте (Griffin, Summer, McMillan, Day, \& Hodapp, 2012; May, 2012). Сазнања о повезаности одређених демографских варијабли и искуствених фактора са ставовима могу дати смернице за одређивање циљне популације и практичних приступа усмерених на формирање позитивнијих ставова особа типичне популације према особама са интелектуалном ометеношћу. Неке од препорука за практично деловање, у складу са наведеним резултатима истраживања, могле би се односити на: обезбеђивање директног искуства (познанства, заједничког учешћа у активностима) особа типичне популације са особама са интелектуалном ометеношћу, рад на формирању позитивних ставова код најмлађих чланова друштва, проширивање знања о особама са интелектуалном ометеношћу и њиховим потребама код мање образованих особа итд.

Негативни ставови према учешћу особа са (интелектуалном) ометеношћу у различитим типовима животних активности (везаним за здравље, образовање, међуљудске односе, запошљавање) могу ометати учешће ових особа у жељеним активностима и остваривање појединих друштвених улога, те је потребно посветити посебну пажњу промени друштвених ставова према овим особама. Како се ставови састоје од три компоненте (когнитивне, афективне и акционе), потребно је радити на промени свих аспеката негативних ставова - знању и уверењима, осећањима и бихевиоралним интенцијама припадника опште популације према особама са интелектуалном ометеношћу. Основни предуслов мењања ставова одређене популације представља систематско и темељно упознавање са смером и интензитетом тих ставова.

\section{Циљ и задаци истражсивања}

Циљ истраживања је утврђивање дирекције и интензитета ставова матураната према друштвеној интеграцији особа са интелектуалном ометеношћу и испитивање повезаности појединих карактеристика испитаника са њиховим ставовима. Истраживачки задаци, стављени у функцију остваривања циља су: (1) утврдити смер (позитивност/негативност) и интензитет ставова матураната према особама са интелектуалном ометеношћу и њиховој инклузији у заједницу, самозаступању и личним правима; (2) испитати да ли постоје разлике у ставовима испитаника у односу на пол, претходно искуство контакта са особама са ометеношћу и интересовање за професионално бављење овом популацијом. 


\section{МЕТОД}

Узорак

Узорак за ово истраживање био је пригодни. Чинило га је 95 ученика четврте године Гимназије „Душан Васиљев” у Кикинди - 35 ученика $(36,8 \%)$ и 60 ученица $(63,2 \%)$.

\section{Хипотезе истраживања}

У складу са претходним истраживањима, формулисане су следеће хипотезе:

(1) Ставови матураната према социјалној интеграцији особа са интелектуалном ометеношћу су позитивни, посматрајући резултат испитаника на скали CLAS-MR у целости;

(2) Ставови ученика женског пола према социјалној интеграцији особа са интелектуалном ометеношћу позитивнији су од ставова ученика мушког пола:

(3) Матуранти који имају искуство контакта са особама са ометеношћу имају позитивније ставове према социјалној интеграцији особа са интелектуалном ометеношћу у односу на ученике који немају такво искуство;

(4) Матуранти који имају рођака или пријатеља са ометеношћу имају позитивније ставове према социјалној интеграцији особа са интелектуалном ометеношћу у односу на ученике који немају такво искуство;

(5) Матуранти који су заинтересовани за професионално бављење популацијом особа са ометеношћу имају позитивније ставове према социјалној интеграцији популације особа са интелектуалном ометеношћу у односу на ученике који немају таква интересовања.

\section{Процедура и инструменти истраживања}

Прикупљање података је изведено по групама у просторијама школе коју испитаници похађају у оквиру једног наставног дана. Након поделе упитника испитаницима, дата су упутства за попуњавање и испитаницима је предочено да је испитивање анонимно и да ће подаци бити коришћени у истраживачке сврхе.

Испитаници су одговарали на шест питања из општег упитника и попуњавали једну скалу процене ставова. Општи упитник састојао се од следећих ставки и питања: пол испитаника, да ли су заинтересовани за професионално бављење популацијом особа са ометеношћу, да ли познају неку особу са ометеношћу, да ли имају блиског рођака или пријатеља који је ометен и, уколико имају, да наведу природу односа са том особом. 
За процену ставова према укључивању особа са интелектуалном ометеношћу у живот заједнице примењена је Скала ставова према животу у заједници - форма за менталну ретардацију (Community Living Attitudes Scale - Mental Retardation Form, CLASMR; Henry et al., 1996). Овај инструмент се састоји од укупно 40 ставки, при чему свака ставка представља једну тврдњу, а од испитаника се очекује да искажу ниво свог слагања са наведеном тврдњом на скали Ликеровог типа (од 1 - апсолутно се не слажем, па до до 6 у потпуности се слажем). Све ставке груписане су у оквиру четири подскале: Оснажсивање, Искључивање, Заштита и Сличност. Подскалу Оснаживање чини 13 ставки, којима се процењују ставови према самозаступању и самосталности особа са интелектуалном ометеношћу (нпр., особи са интелектуалном ометеношћу може се поверити да управља новцем). Ставке које чине подскалу Искључивање (укупно осам) намењене су за процену тенденције испитаника да искључе особе са интелектуалном ометеношћу из живота заједнице (нпр., најбољи начин бриге за особе са интелектуалном ометеношћу је да се оне држе у институцијама). У оквиру подскале Заштита, која се састоји од укупно седам ставки, добијају се подаци о ставу испитаника у односу на потребу особа са интелектуалном ометеношћу да буду заштићене од стране других (нпр., особе са интелектуалном ометеношћу требало би да живе у стационарним установама, где могу да имају помоћ стручног особља). Ставови по питању сличности особа са интелектуалном ометеношћу и особа типичне популације процењују се путем подскале Сличност (нпр., особе са интелектуалном ометеношћу могу бити продуктивни чланови друштва). Позитивност/негативност става за сваку подскалу процењује се у односу на средњу вредност (cut off резултат представља половина од максималног броја бодова на подскали). Позитивније ставове према животу у заједници особа са интелектуалном ометеношћу показују виши резултати на подскалама Оснаживање и Сличност, док је за подскале Заштита и Искључивање обрнуто - виши резултати одсликавају негативније ставове према овој популацији.

Поузданост примењеног инструмената за потребе овог истраживања одређена је Кронбаховим алфа коефицијентом, како за инструмент у целини тако и за појединачне подскале у оквиру инструмента. Задовољавајућа поузданост типа унутрашње конзистенције утврђена је за подскале Оснаживање $(\alpha=0,84)$, Искључивање $(\alpha=0,85)$ и Сличност $(\alpha=0,81)$, док је поузданост подскале Заштита на граници прихватљиве вредности $(\alpha=0,68)$, као и поузданост скале у целини $(\alpha=$ $0,63)$. Поузданост инструмента у целини и подскале Заштита требало би побољшати приликом наредних истраживања у нашој средини другачијим формулисањем или одстрањивањем ставки. Слични подаци по питању поузданости скале CLAS-MR и њених подскала добијени су 
у другом истраживању спроведеном у нашој средини. Поузданост скале у целини и подскала Оснаживање, Искьучивање и Сличност била је у границама прихватљивих вредности $(\alpha>0,7)$, док је поузданост типа унутрашње конзистенције подскале Заштита била нешто нижа ( $\alpha=$ 0,64) (Милачић-Видојевић и сар., 2010).

\section{Статистичке методе}

За описивање независних варијабли примењене су мере дескриптивне статистике (фреквенца, проценат, теоријска аритметичка средина, аритметичка средина резултата испитаника, теоријски распон резултата, минималне и максималне вредности резултата испитаника, стандардна девијација). У циљу испитивања постојања статистички значајних разлика између ставова подгрупа испитаника у односу на пол, претходни контакт, постојање рођака/пријатеља са ометеношћу и професионално интересовање за популацију особа са ометеношћу, примењена је мултиваријантна анализа варијансе (MANOVA).

\section{РЕЗУЛТАТИ ИСТРАЖИВАЬА СА ДИСКУСИЈОМ}

Ставови према особама са интелектуалном ометеношћу

Првом хипотезом истраживања предвиђено је да су ставови према социјалној интеграцији особа са интелектуалном ометеношћу уопштено гледано позитивни на свим подскалама, посматрано на нивоу узорка у целини. У Табели 1 приказана је дескриптивна статистика за све подскале и скалу у целости. Треба имати у виду да, након рекодовања негативно формулисаних ставки, виши резултати на прве две подскале (Оснаживање и Сличност) указују на позитивније ставове према особама са интелектуалном ометеношћу, док нижи резултати на друге две подскале (Заштита и Искључивање) указују на позитивније ставове према овој друштвеној групи. Стога се интерпретација резултата у погледу смера ставова (позитивни/негативни) мора посматрати кроз резултате на подскалама.

Табела 1. Дескриптивни подаџи о резултатима испитаника на скали CLAS-MR

\begin{tabular}{lrrrrrrr}
\hline & N & $\begin{array}{r}\text { Teop. } \\
\text { pacпон }\end{array}$ & $\begin{array}{r}\text { Teop. } \\
\text { AS }\end{array}$ & Min & Max & AS & SD \\
\hline Укупно Оснаживање & 95 & $13-78$ & 45,5 & 15 & 75 & 47,76 & 11,014 \\
Укупно Сличност & 95 & $12-72$ & 42 & 32 & 72 & 56,49 & 8,659 \\
Укупно Искључивање & 95 & $8-48$ & 28 & 8 & 48 & 15,08 & 6,628 \\
Укупно Заштита & 95 & $7-42$ & 24,5 & 13 & 42 & 28,45 & 5,393 \\
Укупно CLAS-MR & 95 & $40-240$ & 140 & 110 & 183 & 147,79 & 13,726 \\
\hline
\end{tabular}


Увид у теоријске вредности и вредности наших испитаника на примењеној скали у целости показује да су њихови ставови позитивни (у просеку већи од теоријске средишње вредности). Релативно висок резултат на подскали Сличност указује на умерено позитивне ставове испитаника према социјалној интеграцији особа са интелектуалном ометеношћу. Резултати испитаника на подскали Оснажсиваґе и Искључивање припадају благо позитивном рангу. Резултати на ове три подскале показују да матуранти из нашег узорка уопштено имају позитивне ставове према социјалној интеграцији ових особа. Супротно нашим очекивањима, просечан резултат целокупног узорка на подскали Заштита показује благо негативан став испитаника. Изузевши подскалу Заштита, чији резултати захтевају пажљиву интерпретацију, може се закључити да добијени резултати на скали CLAS-MR потврђују прву постављену хипотезу у овом истраживању.

Резултати овог истраживања уклапају се у постојеће резултате већине истраживања на ову тему. У истраживању спроведеном у нашој земљи на популацији младих особа (студената Универзитета у Београду) такође су забележени умерено позитивни ставови према особама са интелектуалном ометеношћу (Милачић-Видојевић и сар., 2010). До наведеног закључка Милачић-Видојевић и сарадници дошли су на основу резултата добијених применом три инструмента: скале CLAS-MR, Инвентара за прочену ставова према особама са интелектуалном ометеношћу (Mental Retardation Attitude Inventory, MRAI) и Скале ставова према менталној ретардаиији и еугеници (Scale of Attitudes Toward Mental Retardation and Eugenics, AMRE). Уопштено, често се бележе позитивнији ставови млађих особа (углавном студената) у односу на старије особе према социјалној инклузији особа са интелектуалном ометеношћу (Scior et al., 2013). Позитивнији ставови млађих особа вероватно се могу довести у везу са савременом политиком и тенденцијама по питању начина живљења и улога ових особа у друштву. Док је раније било уобичајено да ове особе живе у сегрегативним условима, у оквиру различитих институција, данас оне углавном станују у заједници, заједно са припадницима опште популације. На тај начин створени су услови за учесталији контакт ове две друштвене групе, тако да присуство особа са интелектуалном ометеношћу у свакодневном животу заједнице постаје уобичајено искуство за припаднике типичне популације.

Одступања од очекиваних резултата на подскали Заштита не морају се нужно тумачити као негативан став према социјалној интеграцији особа са интелектуалном ометеношћу. Имајући у виду ставке које чине ову подскалу (нпр., „Многе особе са ИО воле да раде у заштитним радионицама где су други осетљивији на њихове потребе”; „Особе са ИО би требало да живе у заштићеном окружењу због опасности које вребају у заједници”; „Особе са ИО би требало 
да живе у стационарним установама где могу да имају помоћ стручног особља"), може се закључити да добијени одговори испитаника представљају одраз повишене бриге за ову популацију и њихову безбедност, као и скептичан однос према њиховим могућностима самосталног функционисања и вођења рачуна о себи. Овакав поглед на популацију особа са интелектуалном ометеношћу вероватно је у вези са дугогодишњом праксом институционалног збрињавања ових особа, без постојања довољно прилика за исказивање њихових потенцијала и вештина у домену самосталног функционисања.

\section{Разлике у ставовима}

Постојање разлика у ставовима између група испитаника сагледавано је у односу на следеће варијабле: пол, заинтересованост за професионално бављење особама са ометеношћу, постојање претходног искуства контакта са овим особама и постојање рођачког/пријатељског односа са неком особом са ометеношћу. Резултати по питању појединачног утицаја ових варијабли дати су у Табели 2.

Табела 2. Разлике у ставовима у односу на пол, професионална интересовања, познавање особа са ометеношћу и рођачке/пријатељске везе (MANOVA)

\begin{tabular}{lcccccccc}
\hline & \multicolumn{2}{c}{ Пол } & \multicolumn{3}{c}{$\begin{array}{c}\text { Заинтересованост } \\
\text { за рад }\end{array}$} & \multicolumn{2}{c}{ Контакт } & \multicolumn{3}{c}{ Рођак/пријатељ } \\
са ометеношћу
\end{tabular}

\section{Полне разлике у ставовима}

Приказани резултати (Табела 2) указују на одсуство статистички значајне разлике у односу на пол на скали у целости, као и на свим подскалама. Дакле, испитаници мушког и женског пола из нашег узорка имају сличне ставове према социјалној интеграцији особа са интелектуалном ометеношћу.

Наши налази у складу су са резултатима истраживања групе аутора који су применили CLAS-MR за испитивање ставова према особама са интелектуалном ометношћу у Либији и Великој Британији. Узорком су били обухваћени студенти универзитета и особе ангажоване у непосредном раду са децом са интелектуалном омете- 
ношћу. Значајне разлике по полу нису утврђене ни на једној од подскала (Оснаживање, Искључивање, Заштита и Сличност) за узорак у целини. Само у подузорку испитаника из Либије забележена је разлика између мушких и женских испитаника на подскали Заштита, при чему су позитивније ставове показали испитаници мушког пола (Benomir, Nicolson, \& Beail, 2016). Применом истог инструмента, Сајор и сарадници (Scior et al., 2013) утврдили су значајне разлике на подскалама Сличност и Искључивање (позитивнији ставови жена), док су одговори испитаника различитог пола на друге две подскале били слични. Налази једне канадске студије такође говоре у прилог непостојања разлика у ставовима полова. Ови резултати засновани су на одговорима 625 одраслих испитаника, који су изразили ниво социјалне дистанце према учешћу у различитим активностима заједно са особама са интелектуалном ометеношћу. Ниво испољене социјалне дистанце није се значајно разликовао између мушкараца и жена (Ouellette-Kuntz et al., 2010). Полне разлике у ставовима према социјалној инклузији особа са интелектуалном ометеношћу нису утврђене ни у истраживањима којима су обухваћени студенти Универзитета у Београду (Глумбић, Ћировић 2011; Милачић-Видојевић и сар., 2010).

Постоје и студије у којима је, супротно нашим налазима, постојање разлика у ставовима полова потврђено. У истраживању у којем су испитивани ставови 176 студената према инклузији особа са интелектуалном ометеношћу применом Инвентара за процену ставова према особама са интелектуалном ометеношћу (MRAI), показало се да је пол главна детерминанта ставова испитаника. Студенткиње су имале значајно повољније ставове према популацији са интелектуалном ометеношћу у односу на студенте (Li, Tsoi, \& Wang, 2012). О постојању полних разлика у ставовима сведоче и резултати истраживања спроведеног у Пакистану - жене су изражавале значајно позитивније ставове на свим подскалама CLAS-MR скале у поређењу са мушкарцима (Patka, Keys, Henry, \& McDonald, 2013).

\section{Ставови и претходно искуство контакта}

Трећа хипотеза постављена у овом истраживању односи се на постојање повезаности између искуства контакта са особама са ометеношћу и позитивнијих ставова према особама са интелектуалном ометеношћу. Сви испитаници дали су одговор на питање да ли лично познају неку особу са ометеношћу, при чему је 62,1 \% њих (n = 59) одговорило потврдно, док је 37,9\% испитаника $(\mathrm{n}=36)$ изјавило да не познаје ниједну особу са неким обликом ометености. Применом анализе варијансе, показало се да не постоји разлика у ставовима на скали у целости и њеним подскалама у зависности од личног познавања особе са неким обликом ометености (Табела 2). 
Дакле, испитаници који имају искуство личног контакта са особама са ометеношћу и они који га немају показују сличне ставове према социјалној интеграцији особа са интелектуалном ометеношћу. На основу датих резултата, хипотеза која предвиђа повезаност између познавања неке особе са ометеношћу и ставова према особама са интелектуалном ометеношћу није потврђена.

Искуство контакта са особама са ометеношћу често се у литератури наводи као један од показатеља ставова особа типичне популације према овој друштвеној групи (Keith, Bennetto, \& Rogge, 2015; Li et al., 2012). У нашем истраживању показало се да површни контакт са особама са ометеношћу (само на нивоу познавања ових особа) није повезан са смером и интензитетом ставова. Павловић и сарадници (Павловић, Мастило, Бројчин, Калајџић, \& Рашевић, 2014) наводе да учесталост контакта студената медицине и здравствене неге са особама са ометеношћу није повезана са квалитетом ставова према овој популацији, при чему наглашавају да је учесталост контакта за узорак у целини била, уопштено гледано, ниска. Овакви резултати сугеришу да испод одређеног нивоа интензитета или учесталости контакта неће доћи до промене ставова у смеру позитивнијих вредности. Ли и сарадници (Li et al., 2012) утврдили су да постоји благо позитивна корелација између ставова студената колеџа према интеграцији особа са интелектуалном ометеношћу, са једне стране, и претходног искуства контакта и знањем испитаника о овој популацији, са друге стране.

Налази других аутора говоре у прилог претпоставке да је природа и структурисаност контакта важнија од саме изложености присуству особа са ометеношћу. За разлику од учесталости (квантитета) контакта, квалитет интеракције студената колеџа са особама са интелектуалном ометеношћу показао се значајним за њихове ставове. Студенти који су имали квалитетније искуство контакта са особама са интелектуалном ометеношћу више су подржавали њихову интеграцију у школе и радне средине, залагали се за њихова права, прихватали их као потенцијалне суседе и показивали склоност ка приписивању позитивних карактеристика овој популацији (McManus, Feye, \& Saucier, 2010). Што је квалитет контакта између припадника типичне популације и особа са интелектуалном ометеношћу виши, то су мање предрасуде према овој друштвеној групи. Квалитетније интеракције за резултат имају подржавање аутономије и инклузије особа са интелектуалном ометеношћу и њихово оснаживање у борби за лична права од стране особа типичне популације (Keith et al., 2015).

\section{Ставови и постојање рођака/пријатеља са ометеношћу}

Поред самог познанства са особама са ометеношћу, испитан је и значај постојања блиске везе испитаника са неком особом са оме- 
теношћу (родбинске, пријатељске) за усмерење и интензитет његових ставова. Од укупно 95 испитаника, њих 25,3 \% ( $\mathrm{n}=24)$ изјавило је да има рођака или блиског пријатеља са ометеношћу, док је 74,7 \% $(\mathrm{n}=71)$ дало негативан одговор на ово питање. Резултати анализе разлика у ставовима у односу на постојање блиског односа са неком особом са ометеношћу приказани су у Табели 2.

Постојање статистички значајних разлика, у зависности од тога да ли испитаници имају рођака или пријатеља са ометеношћу, такође није утврђено ни на једној од подскала, као ни укупном резултату на скали CLAS-MR. Дакле, особе из нашег узорка које имају рођака/пријатеља са ометеношћу имају сличне ставове према популацији особа са интелектуалном ометеношћу као испитаници који немају рођака нити пријатеља са неким обликом ометености. Имајући у виду добијене резултате који показују одсуство статистички значајних разлика између група, закључујемо да хипотеза о постојању разлике у ставовима у зависности од постојања рођачке или пријатељске везе са особама са ометеношћу није потврђена.

Овакви резултати одступају од резултата студија у чијем су средишту били ставови особа типичне популације које имају близак однос са особама са ометеношћу, према овој популацији. Према налазима Грифина и сарадника, постојање члана породице или блиског пријатеља са интелектуалном ометеношћу повезано је са већом заинтересованошћу за интеракцију са припадницима ове друштвене групе и подржавањем њихове инклузије (Griffin et al., 2012). Такође, утврђено је и да се ученици (узраста 16-20 година) који имају рођака или пријатеља са интелектуалном ометеношћу више залажу за права ових особа у односу на њихове вршњаке који немају такво искуство (Horner-Johnson et al., 2002, према Jones et al., 2008).

Наши резултати слични су резултатима једног новијег истраживања у ком су испитивани ставови припадника опште популације према особама са интелектуалном ометеношћу. Патка и сарадници (Patka et al., 2013) на узорку су од 452 испитаника применом скале CLAS-MR утврдили да постојање рођака или пријатеља са ометеношћу није било показатељ смера и интензитета ставова испитаника према популацији особа са интелектуалном ометеношћу. Повезаност ставова са постојањем члана породице или блиског пријатеља са ометеношћу није утврђена ни у једној белгијској студији којом је обухваћено 167 адолсцената типичног развоја. Применом мултиваријанте анализе варијансе, постојање рођака или пријатеља са ометеношћу није се показало као значајан фактор у одређивању ставова према овој популацији (Bossaert, Colpin, Pijl, \& Petry, 2011). 


\section{Ставови и професионално интересовање за особе са ометеношћу}

Последња хипотеза овог истраживања била је да матуранти који су заинтересовани за професионално бављење популацијом особа са ометеношћу имају позитивније ставове према социјалној интеграцији особа са интелектуалном ометеношћу у односу на ученике који немају таква интересовања. На питање о постојању интересовања за бављење популацијом особа са ометеношћу у оквиру свог будућег занимања одговор је дало 98,9 \% испитаника $(\mathrm{n}=94)$, док један испитаник $(1,1 \%)$ није одговорио на ово питање. Дистрибуција одговора испитаника показала је да већина испитаника, њих 76,8\% $(\mathrm{n}=73)$ не жели да се професионално бави овим особама, док је $22,1 \%(\mathrm{n}=21)$ њих заинтересовано за рад са овом популацијом.

Резултати на свим подскалама и скали у целини показују да заинтересованост за професионално бављење особама са ометеношћу нема значајну улогу у одређивању ставова испитаника према социјалној интеграцији особа са интелектуалном ометеношћу (Табела 2). Вредности на подскали Оснажсивање приближавају се граници статистичке значајности, али је не достижу, те не можемо говорити о постојању разлика у тенденцији оснаживања особа са интелектуталном ометеношћу код наших испитаника. Стога, може се закључити да добијени резултати не говоре у прилог тачности хипотезе о постојању повезаности између заинтересованости за стручан рад са особама са ометеношћу и ставова према социјалној интеграцији особа са интелектуалном ометеношћу.

Већина истраживача наводи да су ставови према социјалној интеграцији особа са интелектуалном ометеношћу повезани са професионалним интересовањем испитаника за популацију особа са ометеношћу (стручњаци и друге особе које раде са овом популацијом имају позитивније ставове). Улога професионалних интересовања потврђена је и у домаћим и иностраним истраживањима где се показало да студенти „помагачких професија” (психологије, специјалне едукације, социјалног рада), уопштено гледано, имају позитивније ставове према социјалној интеграцији особа са интелектуалном ометеношћу у односу на студенте других факултета (МилачићВидојевић и сар., 2010; Rice, 2009). У једном истраживању спроведеном у Пакистану показало се да особе које су запослене у области пружања услуга особама са интелектуалном ометеношћу имају значајно позитивније ставове према овој друштвеној групи у односу на испитанике који се не баве професионално особама са интелектуалном ометеношћу. Позитивнији ставови огледали су се у виду разлика у резултатима између две групе испитаника на свим подскалама скале CLAS-MR (Patka et al., 2013).

Имајући у виду наведено, наши резултати одступају од очекиваних. Налази једног истраживања у коме су узорак чиниле особе 
радно ангажоване са децом са интелектуалном ометеношћу и студенти универзитета у великој мери су сагласни са нашим налазима. Применом истог инструмента (CLAS-MR), аутори поменутог истраживања утврдили су постојање значајних разлика између студената и стручњака за рад са децом са интелектуалном ометеношћу само на подскали Заштита, док на остале три подскале нису забележене разлике у ставовима. Други ниво анализе односио се на испитивање разлика између две групе студената према области студирања. Како су узорак чинили студенти одељења за психологију и математику, аутори су очекивали да ће позитивније ставове испољити студенти психологије, који би се у будућности могли професионално бавити особама са ометеношћу, за разлику од студената математике. Супротно претпоставци аутора, значајне разлике нису пронађене (Benomir et al., 2016). Значај професионалног усмерења за ставове према социјалној интеграцији особа са интелектуалном ометеношћу био је предмет једне студије у којој су узорак чинили студенти психологије, особље запослено у установама и групним домовима за особе са интелектуалном ометеношћу и група испитаника из шире заједнице. За процену ставова примењена је скала CLAS-MR и Скала независности (Independence Scale), којом се процењује значај који испитаници приписују самосталном учествовању особа са интелектуалном ометеношћу у свакодневним активностима. Разлике у ставовима међу испитиваним групама нису утврђене на подскалама Оснаживање и Искључивање, као ни на Скали независности. Особе које се професионално баве популацијом са интелектуалном ометеношћу показале су позитивније ставове на подскали Заштита у односу на друге две групе. Супротно очекиваном, испитаници који су запослени у установама и групним домовима за особе са интелектуалном ометеношћу сматрали су особе са интелектуалном ометеношћу значајно мање сличним себи (подскала Сличност) него испитаници који не раде са овом популацијом (Chopko, 2011).

\section{ЗАКЉУЧАК}

Значај процењивања ставова матураната огледа се у чињеници да су то особе које ступају у свет одраслих, у коме ће, у ближој или даљој будућности, својим свакодневним понашањем и интеракцијама, а неки и професионалним деловањем, утицати на животе особа са интелектуалном ометеношћу у заједници. Како су ставови углавном блиско повезани са понашањем према одређеној друштвеној групи, важно је познавати смер и интензитет ставова ових младих особа према особама са интелектуалном ометеношћу и релативно рано утицати на њихово мењање у правцу позитивнијих. Подаци добијени овим истраживањем 
сугеришу да су ставови матураната према социјалној интеграцији особа са интелектуалном ометеношћу позитивни на скали у целини и већини подскала примењеног инструмента. Наши испитаници исказали су позитиван став према оснаживању ових особа, њиховом укључивању у активности заједнице и доживљавању ових особа сличним себи. Негативан став испитаници су исказали кроз перципирану потребу особа са интелектуалном ометеношћу да буду смештене у заштићеним животним и радним условима. Пол, познанство и искуство блиског контакта са особама са неким обликом ометености и интересовање за професионално бављење овом популацијом нису се показали повезаним са ставовима према особама са интелектуалном ометеношћу код наших испитаника. Овакви налази усмеравају даљи истраживачки и практичан рад са циљем подстицања већег прихватања социјалне интеграције особа са интелектуалном ометеношћу код особа типичне популације. Теоријске импликације пре свега се односе на даље испитивање детерминанти ставова, док практично деловање треба усмерити на обезбеђивање учесталијег, структурисаног и квалитетног контакта између припадника ове две друштвене групе.

\section{ЛИТЕРАТУРА}

Benomir, A. M., Nicolson, R. I., \& Beail, N. (2016). Attitudes towards people with intellectual disability in the UK and Libya: A cross-cultural comparison. Research in developmental disabilities, 51(1), 1-9.

Bohner, G., \& Dickel, N. (2011). Attitudes and attitude change. Annual Review of Psychology, 62, 391-417.

Bossaert, G., Colpin, H., Pijl, S. J., \& Petry, K. (2011). The attitudes of Belgian adolescents towards peers with disabilities. Research in Developmental Disabilities, 32(2), 504-509.

Burke, J., Bezyak, J., Fraser, R. T., Pete, J., Ditchman, N., \& Chan, F. (2013). Employers' attitudes towards hiring and retaining people with disabilities: A review of the literature. The Australian Journal of Rehabilitation Counselling, 19(01), 21-38.

Chopko, S. (2011). Exploration of Attitudes Toward Individuals with Intellectual Disabilities (Doctoral dissertation, The University of Alabama at Birmingham).

Глумбић, Н., \& Ћировић, Л. (2011). Ставови будућих православних теолога према еугеници и социјалној инклузији особа са интелектуалном ометеношћу [The Attitudes of Future Orthodox Theologians Towards Eugenics and Social Inclusion of the Persons with Intellectual Disability]. Специјална едукаиија и рехабилитаиија, 10(2), 237-247.

Griffin, M. M., Summer, A. H., McMillan, E. D., Day, T. L., \& Hodapp, R. M. (2012). Attitudes toward including students with intellectual disabilities at college. Journal of Policy and Practice in Intellectual Disabilities, 9(4), 234-239.

Henry, D., Keys, C., Jopp, D., \& Balcazar, F. (1996). The community living attitudes scale, mental retardation form: Development and psychometric properties. Mental retardation, 34(3), 149-158.

Jones, J., Ouellette-Kuntz, H., Vilela, T., \& Brown, H. (2008). Attitudes of community developmental services agency staff toward issues of inclusion for individuals with 
intellectual disabilities. Journal of Policy and Practice in Intellectual Disabilities, 5(4), 219-226.

Keith, J. M., Bennetto, L., \& Rogge, R. D. (2015). The relationship between contact and attitudes: Reducing prejudice toward individuals with intellectual and developmental disabilities. Research in Developmental Disabilities, 47(1), $14-26$.

Lee, J. S. (2016). The Effect of Interpersonal Contact on Attitudes Change Toward People with Intellectual or Developmental Disabilities. (Doctoral dissertation). Retrieved from http://escholarship.org/uc/item/760950gw

Li, C., Tsoi, E. W., \& Wang, J. C. (2012). Chinese college students' attitudes toward people with intellectual disabilities: Differences by study major, gender, contact, and knowledge. International Journal of Developmental Disabilities, 58(3), $137-144$.

May, C. (2012). An investigation of attitude change in inclusive college classes including young adults with an intellectual disability. Journal of Policy and Practice in Intellectual Disabilities, 9(4), 240-246.

McManus, J. L., Feyes, K. J., \& Saucier, D. A. (2011). Contact and knowledge as predictors of attitudes toward individuals with intellectual disabilities. Journal of Social and Personal Relationships, 28(5), 579-590.

Милачић-Видојевић, И., Глумбић, Н., \& Каљача, С. (2010). Ставови студената Универзитета у Београду према особама са интелектуалном ометеношћу [The Attitudes of Belgrade University Students Towards People with Intellectual Disabilities]. Педагогија, 65(4), 601-612.

Ouellette-Kuntz, H., Burge, P., Brown, H. K., \& Arsenault, E. (2010). Public attitudes towards individuals with intellectual disabilities as measured by the concept of social distance. Journal of Applied Research in Intellectual Disabilities, 23(2), $132-142$.

Patka, M., Keys, C. B., Henry, D. B., \& McDonald, K. E. (2013). Attitudes of Pakistani community members and staff toward people with intellectual disability. American Journal on Intellectual and Developmental Disabilities, 118(1), 32-43.

Павловић, А., Мастило, Б., Бројчин, Б., Калајџић, О., \& Рашевић, Л. (2014). Детерминанте ставова студената медицине и здравствене његе према особама са ометеношћу [Determinants of the attitudes towards people with disabilities in medical and nursing care students]. Биомедицинска истражсивања, 5(2), 52-59.

Rice, C. J. (2009). Attitudes of undergraduate students toward people with intellectual disabilities: Considerations for future policy makers. College Student Journal, 43(1), 207-215.

Rose, N., Kent, S., \& Rose, J. (2012). Health professionals' attitudes and emotions towards working with adults with intellectual disability (ID) and mental ill health. Journal of Intellectual Disability Research, 56(9), 854-864.

Schalock, R. L., Keith, K. D., Verdugo, M. Á., \& Gómez, L. E. (2010). Quality of life model development and use in the field of intellectual disability. In R. Kober (Ed.), Enhancing the quality of life of people with intellectual disabilities (pp. 17-32). Springer Netherlands.

Scior, K. (2011). Public awareness, attitudes and beliefs regarding intellectual disability: A systematic review. Research in Developmental Disabilities, 32(6), 2164-2182.

Scior, K., Addai-Davis, J., Kenyon, M., \& Sheridan, J. C. (2013). Stigma, public awareness about intellectual disability and attitudes to inclusion among different ethnic groups. Journal of Intellectual Disability Research, 57(11), 1014-1026.

Tervo, R. C., \& Palmer, G. (2004). Health professional student attitudes towards people with disability. Clinical rehabilitation, 18(8), 908-915. 
Wozencroft, A. J., Pate, J. R., \& Griffiths, H. K. (2015). Experiential learning and its impact on students' attitudes toward youth with disabilities. Journal of Experiential Education, 38(2), 129-143.

\title{
ATTITUDES OF HIGH SCHOOL GRADUATES ABOUT SOCIAL INTEGRATION OF PEOPLE WITH INTELLECTUAL DISABILITY
}

\author{
Marija Cvijetić \\ Faculty of Education in Sombor, Sombor, Serbia
}

\begin{abstract}
Summary
Unlike the previously dominant institutional model of care, persons with intellectual disabilities now mostly live in the community. Their physical presence in the community, among other members of it, does not necessarily mean adequate social inclusion and participation in life activities typical for certain age (educational, vocational, recreational, social, etc.). The possibilities for taking over certain social roles and achieving full social integration of those persons are to some extent dependent on the attitudes of the members of typical population towards this social group and their inclusion. Studies of attitudes towards the population of persons with intellectual disabilities and their participation in society tends to indicate that there is a generally positive attitude towards this social group and their rights, but with a certain social distance, manifested as a lack of interest for interacting with these people in different life contexts and activities. Variations in attitudes are present in relation to certain demographic characteristics of the respondents, and depending on the type of life activities in which people with intellectual disabilities should participate.

The aim of this study was to determine the direction and intensity of high school graduates' attitudes towards social integration of persons with intellectual disability and examine the correlation between certain characteristics of the subjects and their attitudes. The direction and intensity of attitudes was examined by the Community Living Attitudes Scale - Mental Retardation Form (CLAS-MR; Henry, Keys, Jopp, \& Balcazar, 1996). The results showed that the attitudes of graduates towards social integration of people with intellectual disability are positive on the scale in general, and three of the four domains of the applied instrument. Our respondents expressed a positive attitude towards the empowerment of these people, their involvement in the community's activities and experiencing these people to themselves. The respondents expressed a negative attitude through the perceived need of people with intellectual disabilities to be placed in protected living and working conditions. The connection between attitudes to gender, previous experience of contact, close contact with people with disabilities and interest for professional work with persons with disabilities was not established.

Knowledge of the direction and intensity of attitudes towards a particular social group is one of the preconditions for their potential changing. Therefore, it is necessary to make efforts in a wider examination of young people's attitudes towards the population with intellectual disabilities, and in accordance with the obtained findings to plan interventions, in order to encourage, as much as possible, the interaction of these two social groups and thus improve social inclusion of people with intellectual disabilities.
\end{abstract}

